\title{
Rekonstruksi Pemidanaan Pelaku Tindak Pidana Terorisme di Indonesia
}

\author{
Cipi Perdana \\ Kejaksaan Negeri Banjarnegara \\ Jln A. Yani 18 Banjarnegara \\ cipiperdana23@gmail.com
}

\begin{abstract}
The issues taken in this research include first, the base of policy justification for the criminal sanction of terrorism; second, the formulation of the accurate criminal sanction of terrorism in the draft of positive law in Indonesia; Third, the forms of criminal sanction that can be offered as a form of reconstruction of criminalization for the terrorists. This is a juridical-normative research in which the result of the research concluded that: first, the justification in the implementation of sanction for criminal act of terrorism is based upon the philosophical sanction implementation supported by the positivism based upon the determinism and philosophically in line with the values as stated in Pancasila and the values of justice as a purpose of the mono-dualistic teachings in criminal law. Theoretically, the implementation of criminal sanction is in line with a number of legal theories such as the modern/combination criminalization theory (Vereningings Theorien), Restorative Justice Theory and double Track System theory. Second, regarding the following regulation revision of the terrorism, there is a need of limitation and conditions of the implementation of criminal sanctions in terms of crime and criminal. Third, the form of criminal sanctions can be done in two ways: The normative form through the Brainwashing program and deradicalization program. Whilst, the social form is done by the way of: correlational separation and the establishment of special institution for the implementation of criminal sanction that is an institution under the Attorney General as the executor of court verdict.
\end{abstract}

Keywords: Reconstruction, criminalization, terrorism, Indonesia.

\section{Abstrak}

Permasalahan dalam penelitian ini, pertama, dasar pembenar kebijakan adanya sanksi tindakan dalam pemidanaan bagi pelaku Tindak Pidana Terorisme; Kedua, formulasi sanksi tindakan yang tepat bagi pelaku Tindak Pidana Terorisme dalam rancangan hukum positif Indonesia; Ketiga, bentuk-bentuk sanksi tindakan yang dapat ditawarkan sebagai bentuk rekonstruksi pemidanaan sebagai bentuk pembaharuan hukum pidana terkait pemidanaan bagi pelaku Tindak Pidana Terorisme. Jenis penelitian ini merupakan penelitian yuridis-normatif. Hasil penelitian menyimpulkan, pertama: alasan pembenar dalam penerapan sanksi tindakan bagi pelaku kejahatan terosisme didasarkan oleh: secara filosofis penerapan sanksi tindakan didukung oleh aliran positif yang beralaskan paham determinisme dan secara filosofis sesuai dengan nilai yang terkandung dalam Pancasila dan nilai-nilai keadilan sebagaimana maksud dari ajaran monodualistik dalam hukum pidana. Secara teoritik, penerapan sanksi tindakan sejalan dengan beberapa teori hukum antara lain Teori pemidanaan gabungan/modern (Vereningings Theorien), Teori Restoratif Justice dan Teori double Track System. Kedua, berkaitan revisi Undang-Undang Terorisme mendatang, perlu adanya batasan dan syarat penerapan sanksi tindakan di dalam revisi Undang-Undang tersebut dalam hal jenis kejahatan dan pelaku kejahatan. Ketiga, bentuk-bentuk pemberian sanksi tindakan dapat dilakukan dalam dua cara, yaitu: bentuk normatif dengan cara program Brainwashing dan program deradikalisasi sedangkan Bentuk Sosial dilakukan dengan cara: Pemisahan pemasyarakatan, dan pembentukan lembaga khusus pelaksanaan sanksi tindakan yaitu sebuah lembaga di berada dibawah Kejaksaan Agung selaku Eksekutor putusan pengadilan.

Kata-kata Kunci: Rekonstruksi, pemidanaan, terorisme, Indonesia 


\section{Pendahuluan}

Hukum haruslah mencerminkan keadilan, sehingga idealnya proses penegakan hukum merupakan salah satu sarana untuk menegakkan keadilan bagi setiap orang. Pembukaan Undang-Undang Dasar (UUD) Tahun 1945 dalam Alenia ke-IV merumuskan bahwa tujuan nasional Negara Republik Indonesia salah satunya adalah mewujudkan suatu keadilan sosial bagi seluruh rakyat Indonesia. Mewujudkan dan menegakkan keadilan-pun merupakan salah satu perintah Allah SWT ${ }^{1}$. Pada konteks penegakan hukum pidana (penal law enforcement), sebagai upaya pencapaian keadilan dapat dilaksanakan salah satunya dengan cara melakukan pencegahan dan penanggulangan suatu kejahatan yang merupakan bagian dari kebijakan kriminal (criminal policy). Kebijakan tersebut dilakukan dengan menggunakan sarana hukum pidana (sarana penal) khususnya pada tahap kebijakan yudikatif (in-abstracto) hingga tahap aplikatif dan tahap eksekusi (penegakan hukum pidana in-concreto). Idealnya, pada setiap tahapannya harus tetap memperhatikan dan mengarah pada tercapainya tujuan nasional Negara Indonesia sebagaimana termaktub pada Pembukaan UndangUndang Dasar (UUD) Tahun 1945 tersebut yaitu mewujudkan keadilan yang merata bagi seluruh rakyat Indonesia.

Kebijakan penanggulangan kejahatan seharusnya selalu mampu mengikuti perkembangan dari kejahatan itu sendiri oleh karena perkembangan hukum mengakibatkan berkembangnya metode kejahatan begitu pula sebaliknya. Salah satu jenis kejahatan yang terus berkembang dan menjadi perhatian baik secara global maupun nasional bangsa ini adalah kejahatan terorisme. Kejahatan terorisme bahkan termasuk Prolegnas baik dalam Rancangan Undang-Undang Kitab Undang-Undang Hukum Pidana (RUU KUHP) maupun revisi Undangundang Terorisme karena masyarakat menilai aturan yang ada belum mampu dan maksimal menanggulangi kejahatan terorisme.

Mengupas tentang kejahatan terorisme, pada prinsipnya tidak dapat terlepas pada persoalan pokoknya yaitu sebagai salah satu bentuk kejahatan (crime).

${ }^{1}$ Surat Al-Maidah ayat 8 yaitu: "Hai orang-orang yang beriman hendaklah kamu jadi orang yang selalu menegakkan kebenaran karena Allah, menjadi saksi dengan adil. Dan janganlah sekali-kali kebencianmu terhadap sesuatu kaum, mendorong kamu untuk berlaku tidak adil. Berlaku adillah, karena adil itu lebih dekat kepada takwa. Dan bertakwalah kepada Allah, sesungguhnya Allah Maha Mengatahui apa yang kamu kerjakan”. 
Menurut Ali Masyar secara global kejahatan terjadi disebabkan kesewenangwenangan tindakan yang dilakukan oleh sebagian negara besar -melalui aparatur pemerintahannya- seperti kerapkali memunculkan kekecewaan bahkan yang paling ekstrim adalah memunculkan radikalisme pada negara atau kelompok tertentu yang merasa tertindas. Perbuatan-perbuatan radikal seperti inilah yang akhirnya melahirkan perbuatan teror atau terorisme. ${ }^{2}$

Abdul Wahid menyatakan bahwa terorisme lahir dan tumbuh dari rasa kekecewaan akibat perlakuan tidak adil yang berlangsung lama dan tidak ada harapan untuk adanya perubahan. ${ }^{3}$ Namun, kasus terorisme yang ada di Indonesia ada motif lain yang dapat mendasari seseorang melakukan kegiatan teror yaitu adanya keyakinan dan fanatisme keagamaan yang negatif, yang pada akhirnya menganggap sebuah pemerintahan atau ajaran agama yang lain adalah salah. Faktor tersebut yang mendorong munculnya tindakan radikal sekelompok orang yang mencari perhatian pemerintah bahkan dunia dengan menciptakan ketakutan di masyarakat, menimbulkan suatu korban jiwa atau harta benda masyarakat.

Pemidanaan bagi pelaku terorisme dalam hukum positif di Indonesia tidak hanya dikenakan kepada para pelaku utama seperti pelaku pengeboman atau pembunuhannya, melainkan juga dikenakan terhadap orang yang memiliki keterkaitan dengan pelaku kejahatan tersebut, misalnya orang yang dengan sengaja memberi bantuan atau kemudahan kepada pelaku, atau memberikan uang atau dukungan finansial kepada pelaku ${ }^{4}$, orang yang menyembunyikan pelaku terorisme ataupun orang yang menyembunyikan informasi tentang tindak pidana terorisme sebagaimana diatur dalam Pasal 13 Undang-Undang Nomor 15 Tahun 2003 tentang Pemberantasan Tindak Pidana Terorisme.

Begitu banyaknya pelaku terorisme yang telah dikenai sanksi pidana penjara, ternyata tidak menyurutkan para pelaku untuk terus berbuat teror sebagai bentuk pembalasan dendam bagi kelompoknya yang telah dilakukan pemidanaan. Secara

2 Ali Masyar, Gaya Indonesia Menghadang Terorisme: Sebuah Kritik. Atas Kebijakan Hukum Pidana Terhadap Tindak Pidana Terorisme di Indonesia, CV. Mandar Maju, Bandung, 2009, hlm. 1.

3 Abdul Wahid, Dkk, Kejahatan Terorisme: Perspektif Agama, HAM dan Hukum, PT Refika Aditama, Bandung, 2004, hlm. 4.

${ }^{4}$ Ketidaksingkronan pengaturan tindak pidana pendanaan terorisme dalam UU No. 15 Tahun 2003, UU No. 9 Tahun 2013 dan Rancangan KUHP menjadi salah satu kendala dalam pencegahan dan pemberantasan tindak pidana terorisme. Lebih lanjut baca Randy Pradityo, "Kebijakan Hukum Pidana dalam Upaya Penganggulangan Tindak Pidana Pendanaan Terorisme" dalam Jurnal Rechtsvinding, Volume 5, Nomor 1, April 2016, hlm.28-30. 
subyektif, para pelaku yang telah dikenai sanksi pidana setelah menjalani hukuman (recidive) ternyata tidak mampu memberikan efek perbaikan baik kepada dirinya sendiri maupun kepada kelompoknya. Sifat-sifat radikal yang ada dalam keyakinan dan pemikiran pelaku masih tetap tertanam kuat, meskipun mereka telah menjalani hukuman. Hukuman penjara ternyata tidak mampu memiliki efek rehabilitasi dan resosialisasi secara subyektif bagi pelaku setelah menjalani pemidanaan. Dalam praktiknya, penjara dijadikan sebagai titik balik bagi terpidana terorisme untuk bertindak lebih nekat. Sejak bom Hotel Marriot kedua 2009, aksi terorisme di Indonesia melibatkan mantan narapidana terorisme. Keterlibatan kedua kalinya, karena adanya peningkatan peran dan aksi. Misalnya, Urwah, salah satu pelaku pengeboman Hotel Marriot 2009. Pertama kali ditangkap, Urwah berperan menyembunyikan informasi keberadaan Noordin M. Top. Aksi kedua, Urwah menjadi salah satu perancang serangan maut itu. Demikian juga dengan Afif alias Sunakim, pelaku bom Sarinah 2016. Awalnya, Afif hanya terlibat dalam pelatihan militer di Aceh pada 2010. Setelah bebas, Afif menjadi pelaku utama serangan di awal tahun ini. ${ }^{5}$

Bila mengkaji hubungan kausalitas antara kejahatan terorisme yang banyak dilakukan oleh residivis maupun oleh orang-orang yang memiliki hubungan erat dengan pelaku sebelumnya, menimbulkan pertanyaan dan perdebatan mengenai apakah tujuan pemidanaan telah menjadi pembicaraan dari zaman ke zaman dan menjadi isu sentral dalam hukum pidana telah tercapai dalam praktiknya. Oleh karena pidana atau hukuman selalu berkenaan dengan tindakan dilakukan oleh negara dengan berlandaskan hukum yang tentunya dapat menjadi sarana pencegahan dan penanggulangan kejahatan itu sendiri.

Perkembangan pidana dan pemidanaan pada aliran hukum modern, sistem pemidanaan mulai berorientasi pada pelaku dan perbuatan (daad-dader straafrecht) yaitu jenis sanksi yang diterapkan bukan hanya sanksi pidana tetapi juga meliputi sanksi tindakan. Aspek pemidanaan merupakan salah satu aspek yang menjadi sorotan masyarakat terhadap upaya pemberantasan kejahatan terorisme.

5 https://www.tempo.co/read/kolom/2016/11/22/2429/penjara-tak-membuatnya-jera, diakses pada tanggal 15 Juli 2016. 
Berkembangnya jaringan teroris dan fenomena pelaku oleh recidivis, serta penegakan hukumnya menjadi pertanyaan serius apakah kebijakan pemidanaan yang ada saat ini masih relevan atau memerlukan pembaharuan hukum pidana materiil sebagaimana juga diungkap oleh Chairul Huda yang menyatakan bahwa revisi UU Terorisme sudah menjadi sebuah kebutuhan. ${ }^{6}$ Oleh karena itu diperlukan kajian ilmiah yang komprehensif dan mendalam mengenai konsep pemberlakuan sanksi tindakan bagi pelaku tindak pidana terorisme dalam upaya pencegahan dan penanggulangan kejahatan terorisme.

\section{Rumusan Masalah}

Berdasarkan uraian di atas, permasalahan dalam penelitian ini yaitu: pertama, apa dasar pembenar kebijakan adanya sanksi tindakan dalam pemidanaan bagi pelaku Tindak Pidana Terorisme? Kedua, bagaimana formulasi sanksi tindakan yang tepat bagi pelaku Tindak Pidana Terorisme dalam rancangan hukum positif Indonesia? Ketiga, bagaimana bentuk-bentuk sanksi tindakan yang dapat ditawarkan sebagai bentuk rekonstruksi pemidanaan sebagai bentuk pembaharuan hukum pidana terkait pemidanaan bagi pelaku Tindak Pidana Terorisme?

\section{Tujuan Penelitian}

Tujuan penelitian ini untuk mendapatkan suatu kajian akademis yang menyeluruh (general) dan mendalam (in-depth) guna: pertama, mengetahui dan menjelaskan dasar pembenar kebijakan adanya sanksi tindakan dalam pemidanaan bagi pelaku tindak pidana terorisme dalam hukum positif Indonesia; Kedua, mengetahui dan menjelaskan formulasi sanksi tindakan yang tepat bagi pelaku tindak pidana terorisme dalam rancangan hukum positif Indonesia; Ketiga, mengetahui dan menjelaskan bentuk-bentuk sanksi tindakan yang dapat ditawarkan sebagai bentuk rekonstruksi pemidanaan sebagai bentuk pembaharuan hukum pidana terkait pemidanaan bagi pelaku Tindak Pidana Terorisme.

${ }^{6}$ http:/ / huda-drchairulhudashmh.blogspot.co.id/2016/01/uregensi-revisi-undang-undang-terorisme. html, diakses tanggal 15 Maret 2016 


\section{Metode Penelitian}

Jenis penelitian yang digunakan adalah penelitian yuridis-normatif, karena lebih mengedepankan pengkonsepsian hukum sebagai law in doctrine yang keseluruhannya ternaung dalam pendekatan konseptual penelitian. ${ }^{7}$ Penelitian ini menggunakan 2 (dua) pendekatan, yaitu: a. Pendekatan yuridis-normatif, yaitu pendekatan dalam memahami hukum dari kaidah filsosofis aturan hukum tersebut beserta landasan pembenaran pemberlakuan suatu aturan hukum. Metode berpikir yang digunakan adalah metode berpikir deduktif yaitu suatu cara berpikir dengan menarik kesimpulan dari sesuatu yang sifatnya umum dan kesimpulan itu ditujukan untuk sesuatu yang sifatnya khusus; ${ }^{8}$ b. Pendekatan kebijakan, yakni pendekatan dalam pembuatan keputusan yang berorientasi kepada tujuan yang hendak dicapai. ${ }^{9}$ Pendekatan kebijakan diperlukan terkait dengan kebijakan penerapan sanksi tindakan terhadap pelaku kejahatan terorisme di Indonesia. Pendekatan kebijakan mencakup pengertian yang saling terkait antara pendekatan yang berorientasi pada tujuan, pendekatan yang rasional, serta pendekatan yang berorientasi pada nilai. ${ }^{10}$

Data yang digunakan dalam penelitian ini adalah data sekunder yang terdiri dari bahan hukum primer, bahan hukum sekunder, dan bahan hukum tersier. Bahan hukum primer berupa Undang-Undang Dasar Republik Indonesia 1945, Kitab Undang-Undang Hukum Pidana (KUHP), Rancangan Undang-Undang Kitab Undang-Undang Hukum Pidana (RUU KUHP), dan Undang-Undang Nomor 15 Tahun 2003 tentang Pemberantasan Tindak Pidana Terorisme. Bahan hukum sekunder berupa buku, jurnal, hasil penelitian yang terkait dengan hukum pidana dan pemidanaan, sanksi pidana dan sanksi tindakan, serta bahan lain yang mengkaji tentang pembaharuan hukum pidana. Sedangkan bahan hukum tersier adalah Kamus Besar Bahasa Indonesia, kamus hukum, dan ensiklopedi serta bahan lain yang menunjang. Teknik pengumpulan data yang akan digunakan dalam penelitian ini dilakukan dengan cara studi kepustakaan.

\footnotetext{
${ }^{7}$ Soerjono Soekanto, Pengantar Penelitian Hukum, Ctk. Ketiga, UI Press, Jakarta, 2010, hlm. 51.

${ }^{8}$ Sedarmayanti \& Syarifudin Hidayat, Metodologi Penelitian, CV. Mandar Maju, Bandung, 2002, hlm. 23.

${ }^{9}$ Sulisty Basuki, Pengantar Dokumentasi Ilmiah, Kesaint Balanc, Jakarta, 1989, hlm. 4.

${ }^{10}$ Barda Nawawi Arief, Kebiiakan Legislatif Dalam Penanggulangan Kejahatan dengan Pidana Penjara, Universitas Diponegoro, Semarang, 1994, hlm. 61.
} 
Pengolahan, analisis dan konstruksi data penelitian hukum normatif dapat dilakukan dengan melakukan analisis terhadap kaidah hukum dan kemudian dikonstruksi kedalam kategori-kategori atas dasar pengertian- pengertian dasar dari sistem hukum tersebut. ${ }^{11}$

\section{Hasil Penelitian dan Pembahasan}

Awalnya terorisme dikategorikan sebagai kejahatan terhadap negara (Crime Against State), tetapi lambat laun berkembang menjadi kejahatan terhadap kemanusiaan (Crime Against Humanity). ${ }^{12}$ Kejahatan terorisme merupakan salah satu bentuk kejahatan berdimensi internasional. Perserikatan Bangsa Bangsa dalam kongresnya di Wina Austria tahun 2000 mengangkat tema The Prevention of Crime and The Treatment of Offenders, antara lain menyebutkan terorisme sebagai suatu perkembangan perbuatan dengan kekerasan yang perlu mendapat perhatian. Keadaan yang mendesak menyebabkan Pemerintah Republik Indonesia telah memulai mengambil langkah-langkah untuk PERPU RI Nomor 1 Tahun 2002 tentang Pemberantasan Tindak Pidana Terorisme yang kemudian di undangkan dengan UU RI No. 15 tahun 2003 sebagai langkah antisipatif untuk melakukan pencegahan dan penanggulangan tindak pidana terorisme.

Persoalan pertama yang muncul manakala berbicara kejahatan terorisme adalah definisi terorisme itu sendiri, karena hingga saat ini belum ada definisi terorisme yang diterima secara universal (there is not universsaly accepted definition of terrorism). Kejahatan berarti perilaku yang bertentangan dengan nilai-nilai dan norma-norma yang berlaku yang telah disahkan oleh hukum tertulis. ${ }^{13}$ Walter Laquer yang menyatakan tidak akan mungkin ada sebuah definisi yang bisa mengcover ragam terorisme yang pernah muncul dalam sejarah. Secara etimologis, terorisme berarti suatu paham. Terorisme berasal dari kata latin "terrere" yang kurang lebih berarti membuat gemetar atau mengetarkan. ${ }^{14}$ Pengertian menurut sisi tata bahasa, Black Law

11 Soerjono Soekanto, Pengantar Penelitian Hukum, Grafindo, Jakarta, 2006, hlm. 225.

12 Keterangan Pemerintah tentang diterbitkannya Perpu Nomor 1 Tahun 2002 Tentang Pemberantasan Tindak Pidana Terorisme yang disampaikan oleh Menteri Kehakiman dan Hak Asasi Manusia, Departemen Kehakiman dan Hak Asasi Manusia, 2002, hlm 8.

${ }^{13}$ Indrawan WS, Kamus Lengkap Bahasa Indonesia, Lintas Media, Jombang, tt., hlm. 242.

${ }^{14}$ Mahrus Ali, Hukum Pidana Teroriseme Teori dan Praktik, Gramata Publishing, Jakarta, 2012, hlm. 1-2. 
Dictionary mengartikan terorisme sebagai "The use or threat of violence to intimidate or cause panic, especially as a means of affecting political conduct."15

Motivasi seseorang untuk menjadi teroris sangatlah beragam, bahkan setiap individu teroris memiliki alasannya tersendiri. Menurut Levin, motivasi dan dampaknya yang luas ini merupakan karakteristik pembeda secara sederhana antara kejahatan teroris dengan kejahatan lainnya. Menurutnya, kejahatan konvensional pada umumnya hanya berorientasi pada harta, uang atau menyakiti korban secara fisik. Namun pada kejahatan teror, secara umum bertujuan untuk membangkitkan gejolak sosial ataupun mengirim pesan-pesan ancaman atau intimidasi yang dapat menimbulkan instabilitas keamanan secara luas, dan dapat mendorong terjadinya perubahan politik ataupun perubahan kebijakan (dari pihak lawan). ${ }^{16}$

Witthaker menambahkan kriteria yang umumnya dapat ditemui pada kelompok teroris yaitu: kegiatan terencana, dilandasi tujuan politik, menggunakan kekerasan untuk menyerang atau mengintimidasi pemerintah atau masyarakat secara umum, menimbulkan ketakutan atau ketidakstabilan keamanan. Awalnya bersifat lokal dalam negeri tetapi kemudian dapat berkembang lintas negara. ${ }^{17}$

Undang-Undang Nomor 15 Tahun 2003 tentang Pemberantasan Tindak Pidana Terorisme mencantumkan orang dan korporasi sebagai subyek tindak pidana yang dapat dipertanggungjawabkan dalam suatu tindak pidana terorisme. Ketentuan delik dalam Undang-Undang Nomor 15 Tahun 2003 diawali dengan kata-kata setiap orang. Dalam hukum pidana konsep "pertanggungjawaban" merupakan konsep sentral yang dikenal dengan ajaran kesalahan. Dalam bahasa latin, ajaran kesalahan dikenal dengan sebutan mens rea yang dilandaskan dalam suatu perbuatan tidak mengakibatkan seseorang bermasalah, kecuali jika pikiran orang itu jahat. Dalam bahasa inggris dokrin tersebut dirumuskan dengan an act does not make a person gulity, unless the mind is legally blameworthy, berdasarkan asas tersebut, ada dua syarat yang harus dipenuhi untuk dapat memidana seseorang

\footnotetext{
${ }^{15}$ Bryan A. Garner, Black's Law Dictionary: English Edition, West Publishing Co, USA, 1990, hlm. 1513.

${ }^{16}$ Jack Levin, The Roots of Terrorism Domestic Terrorism, Chelsea House, New York, 2006, hlm. 6.

${ }_{17}$ J. David Whittaker, Terorism Understanding The Global Threat, Pearson Education, London, 2002, hlm. 10.
} 
teroris, yaitu ada perbuatan lahiria yang terlarang/perbuatan pidana (actus reas) dan ada sikap batin jahat/tercela (mens rea). ${ }^{18}$

Undang-Undang Nomor 15 Tahun 2003 tentang Pemberantasan Tindak Pidana Terorisme dalam rumusan tindak pidana terorisme hampir selalu tercantum unsur dengan sengaja atau kealpaan. Bentuk sanksi pidana yang dijatuhkan terhadap pelaku terorisme ada tiga, yaitu pidana mati, pidana penjara, dan pidana denda untuk pelaku korporasi. Pola pengancaman hukum pidana merupakan salah satu cermin yang sangat dipercaya diberikan ke dalam suatu peradaban yang merefleksikan nilai-nilai fundamental pada saat ini. Dalam sejarah hukum pidana, terutama tentang sanksinya, akan sulit untuk percaya bahwa manusia benar-benar merupakan makhluk yang sangat kejam. Betapa tidak jenis-jenis pidana yang dikenal dari ujung timur sampai ke ujung barat dan dari ujung utara ke selatan planet ini semuanya bertumpu kepada pembalasan (retribution) dan cara pelaksanaannya pun sangat tidak manusiawi. ${ }^{19}$

Pemerintah Indonesia telah menetapkan 3 (tiga) paradigma yang dipandang cocok dalam konteks kultur politik yang berkembang, yaitu: pertama, adalah perlindungan kedaulatan wilayah negara kesatuan Republik Indonesia; kedua, adalah perlindungan hak asasi warga negara Republik Indonesia, baik yang tinggal di dalam negeri maupun di luar negeri; dan ketiga, adalah perlindungan hak asasi tersangka/terdakwa pelaku tindak pidana terorisme yang sudah merupakan hak universal dan oleh karenanya tidak boleh diabaikan. ${ }^{20}$

J.E. Sahetapy telah memperingatkan bahwa "Pembebanan pidana (een strafpleggen), harus diusahakan agar sesuai dan seimbang dengan nilai-nilai kesadaran hukum, nilai-nilai mana bergerak menurut perkembangan ruang, waktu dan keadaan yang mewajibkan pengenaan suatu nestapa yang istimewa sifatnya, sebagai suatu reaksi terhadap aksi yang memperkosa tata (hukum) yang sedang menjatuhkan pidana. ${ }^{21}$

Dengan kata lain, untuk mengukur sejauh mana suatu jenis sanksi pidana tersebut dapat memenuhi tujuan pemidanaan yang ditentukan oleh sistem hukum

18 Mahrus Ali, Op. Cit., hlm. 221. hlm. 221.

${ }_{19}$ Andi Hamzah, Kapita Selekta Hukum Pidana Mengenang Oemar Seno Adji, Ghalia Indonesia, Jakarta, 1995,

20 Romli Atmasasmita, Masalah Pengaturan Terorisme dan Perspektif Indonesia, Badan Pembinaan Hukum Nasional Departemen Kehakiman dan HAM RI, Jakarta, 2002, hlm. 2.

21 J.E. Sahetapy, Pidana Mati Dalam Negara Pancasila, Citra Aditya, Bandung, 2007, hlm. 37. 
pidana yang bersangkutan. Hal ini mengingat, pidana pada hakikatnya hanya merupakan "alat" untuk mencapai tujuan. Berbagai teori pemidanaan yang mengemuka pada jamannya telah merumuskan tujuan pemidanaan yang berbedabeda. ${ }^{22}$ Namun satu hal yang patut dicatat adalah bahwa perkembangan teori pemidanaan tersebut menunjukkan pergeseran falsafah pemidanaan dari falsafah "menghukum" ke falsafah "pembinaan", termasuk di Indonesia.

\section{Dasar Filosofis Pembenaran Pemidanaan Berupa Sanksi Tindakan bagi Pelaku Terorisme}

Penerapan sanksi tindakan sebagai sanksi bagi pelaku kejahatan terosisme didasarkan oleh beberapa aliran atau pendapat. Pertama, Aliran positif melihat kejahatan secara empiris dengan menggunakan metode ilmiah untuk mengkonfirmasi fakta-fakta di lapangan dalam kaitannya dengan terjadinya kejahatan. Aliran ini beralaskan paham determinisme yang menyatakan bahwa seseorang melakukan kejahatan bukan berdasarkan kehendak karena manusia tidak mempunyai kehendak bebas dan dibatasi oleh berbagai faktor, baik watak pribadinya, faktor biologis, maupun faktor lingkungan. Oleh karena itu, pelaku kejahatan tidak dapat dipersalahkan dan dipidana, melainkan harus diberikan perlakuan (treatment) untuk resosialisasi dan perbaikan si pelaku. ${ }^{23}$

Kata determinisme berasal dari bahasa latin determinare yang berarti menentukan batas atau membatasi. Determinisme merupakan filosofi yang menyatakan bahwa segala sesuatu di dunia ini, termasuk manusia, ditentukan oleh hukum sebab akibat. ${ }^{24}$ Determinisme menyatakan bahwa perilaku manusia ditentukan oleh faktor-faktor yang dapat ditunjukkan secara jelas. Faktor-faktor itu berupa motif yang tidak disadari, pengaruh masa kecil, pengaruh keturunan, pengaruh kultural, dan lain sebagainya. Kedua, pandangan yang radikal dipelopori dan dipertahankan oleh F. Gramatica, yang salah satu tulisannya berjudul “the fight

\footnotetext{
22 Penggunaan teori pemidanaan dapat dilihat dalam pertimbangan hakim, yaitu terhadap tindak pidana yang relatif berat, diutamakan pemidanaan yang mengandung unsur pembalasan, sedangkan dalam tindak pidana yang relatif ringan, tujuan pidana dapat lebih ditekankan kepada pribadi pelaku untuk di-resosialisasi. M.A. Kholiq dan Ari Wibowo,"Penerapan Teori Tujuan Pemidanaan dalam Perkara Kekerasan terhadap Perempuan: Studi Putusan Hakim” dalam Jurnal Hukum Ius Quia Iustum, No. 2 Volume 23 April 2016, hlm. 202-203. $22-24$.

${ }^{23}$ J. Robert Lily et, al., Criminological Theory, Context and Consequences, SAGE Publication, London, 1995, hlm.

${ }^{24}$ Antony Harrison Barbet, Mastering Philosophy, The Macmillan Press Ltd, London, 1990, hlm. 326.
} 
against punishment" (La Lotta Contra La Pena). Gramatika berpendapat bahwa, "hukum perlindungan sosial harus menggantikan hukum pidana yang ada sekarang. Tujuan utama dari hukum perlindungan sosial adalah mengintegrasikan individu ke dalam tertib sosial dan bukan pemidanaan terhadap perbuatannya". ${ }^{25}$

Ketiga, Pandangan moderat dipertahankan oleh Marc Ancel (Perancis) yang menanamkan aliran sebagai Defence Sosiale Nouvelle atau New Social Defence atau Perlindungan Sosial Baru. Menurut Marc Ancel, tiap masyarakat mensyaratkan adanya tertib sosial, yaitu seperangkat peraturan-peraturan yang tidak hanya sesuai dengan kebutuhan untuk kehidupan bersama, tetapi sesuai dengan aspirasi warga masyarakat pada umumnya. Oleh karena itu, peranan yang besar dari hukum pidana merupakan kebutuhan yang tidak dapat diletakkan bagi suatu sistem hukum. ${ }^{26}$

Mengenai sanksi tindakan, Roeslan Saleh menyatakan bahwa jika pidana dalam usahanya mencapai tujuannya tidaklah semata-mata dengan jalan menjatuhkan pidana, tetapi di samping itu juga dengan menggunakan tindakan, jadi, di samping pidana ada pula sanksi tindakan. Ini ditujukan semata-mata pada prevensi khusus. Maksudnya tindakan ini adalah untuk menjaga kemanan dari pada masyarakat terhadap orang-orang yang banyak sedikit berbahaya dan akan melakukan perbuatan pidana. ${ }^{27}$

Sanksi tindakan ditujukan pada pelaku pidana yang didasarkan pada perlindungan, agar pelaku tindak pidana akan menjadi lebih baik dan bukan semata-mata untuk tujuan pembalasan. Tindakan juga berorientasi ke depan sehingga berupaya agar pelaku lebih mengerti bahwa yang dilakukan adalah tidak benar dan melanggar hukum, sehingga kelak tidak akan mengulanginya lagi. Menurut H.L. Packer tentang sanksi tindakan, "the primary purpose of treatment is to benefit the person being treated. The focus is not on his conduct, past or future, but on helping him. ${ }^{28}$

${ }^{25}$ Muladi dan Barda Nawawi Arief, Teori-Teori dan Kebijakan Pidana, Alumni, Bandung, 2010, hlm. 35.

${ }^{26}$ Marc Ancel, Sosial Defence, Modern Approach to the Criminal Problem, Roatledge \& Paul Keagen, London, 1965, hlm. 74.

${ }^{27}$ Roeslan Saleh, Stelsel Pidana Indonesia, Aksara Baru, Jakarta, 1983, hlm. 9.

${ }^{28}$ Herbert L. Packer, The Limits of The Criminal Sanction, Stanford University Press, California, tt, hlm. 25. 
Aliran determinisme hukum ini mempertimbangkan bahwa tindakan bagi pelaku diperlukan dengan mempertimbangkan faktor psikologis terpidana terorisme yang mendasarkan pada sebuah faktor kejiwaan yaitu keyakinan dalam berbuat kejahatan. Oleh karenanya diperlukan suatu proses rehabilitasi jiwa yang disebut dengan deradikalisasi. Sudah saatnya kebijakan ini menjadi pertimbangan dalam penerapan bagi pelaksanaan pemidanaan terhadap pelaku tindak pidana terorisme di Indonesia. Hal ini disebabkan karena pelaku tindak pidana terorisme hampir didominasi oleh motif keyakinan yang membutuhkan suatu recovery jiwa dan resosialisasi perspektif keyakinan dalam masyarakat.

Kajian Nilai yang terdapat dalam Pancasila, sila pertama yaitu Ketuhanan Yang Maha Esa menurut Notonagoro adalah causa prima, pengakuan dan keyakinan atas Tuhan Yang Maha Esa diamalkan hampir oleh seluruh Bangsa Indonesia. Untuk itu ancaman dan pelaksanaan pidana harus berpedoman pada sila Ketuhanan Yang Maha Esa. Untuk melihat seberapa penting nilai-nilai yang bersumber dari Pancasila itu dijadikan sebagai dasar atau landasan dalam kebijakan berbangsa dan bernegara termasuk di dalamnya kebijakan legislatif tentang sanksi pidana terhadap terorisme akan dikaji sejauhmana hubungan (kedudukan) Pancasila dalam kehidupan bermasyarakat, berbangsa dan bernegara di Indonesia.

Noor MS Bakry lebih lanjut mengemukakan Pancasila menyeimbangkan sifat individu dan sifat sosial dalam kehidupan bermasyarakat, berbangsa dan bernegara. Sehingga Pancasila merupakan titik perimbangan yang dapat mempertemukan antara aliran individualisme dan aliran kolektifisme untuk menegakkan negara modern yang menempuh jalan tengah dengan aliran monodualistik atau sering disebut negara berfaham integralistik". ${ }^{29}$

Perspektif Agama yang pada pokoknya merupakan risalah yang disampaikan tuhan kepada nabi sebagai petunjuk bagi manusia dan hukumhukum sempurna untuk dipergunakan manusia dalam menyelenggarakan tata cara hidup yang nyata serta mengatur hubungan dengan dan tanggung jawab

${ }^{29}$ Noor MS Bakry, Pancasila Yuridis Kenegaraan, Liberty, Yogyakarta, 1994, hlm. 61. 
kepada Allah, dirinya sebagai hamba Allah. ${ }^{30}$ Terorisme pada kenyataannya ditafsirkan sekehendak hati negara-negara tertentu untuk menghantam organisasi, maupun pribadi yang disinyalir sebagai teroris menurut versi mereka siapapun. Teror yang terlarang adalah teror yang meresahkan keamanan masyarakat luas. Membunuh orang yang tidak bersalah sebagai tumbal bagi dosa yang tidak mereka lakukan mengucurkan darah, melululantahkan rumah, dan mengganggu kehormatan orang-orang tidak berdosa tanpa perasaan bersalah sedikitpun. ${ }^{31}$

Hukum Islam tidak hanya dikenai sanksi supernatural (dosa, murka Tuhan dan neraka), tetapi juga diancam berbagai sanksi hukum. Fikih jinaya khusus membahas sanksi pidana terhadap perbuatan manusia yang harus dijalankan oleh pemerintah. 32 Dalam hukum Islam dikenal dengan hukuman mati untuk para pemberontak yang dalam hal ini teroris. Para ulama mazhab sepakat harus adanya proses dialog terlebih dahulu sebelum hukuman mati dieksekusi. Proses dialog dalam rangka menemukan faktor yang mengakibatkan para pembangkang melakukan pemberontakan. Jika mereka menyebut beberapa kezaliman atau penyelewengan yang dilakukan oleh imam dan mereka memiliki fakta-fakta yang benar maka imam harus berupaya menghentikan kezaliman dan penyelewengan tersebut.

Upaya berikutnya adalah mengajak para pemberontak diajak kembali tunduk dan patuh kepada imam atau kepala negara. Apabila mereka bertaubat dan mau kembali patuh maka mereka dilindungi, sebaliknya jika mereka menolak untuk kembali, barulah diperbolehkan untuk memerangi dan membunuh mereka. ${ }^{33}$

Di beberapa negara yang melakukan pembaharuan dalam pemidanaan antara lain Yaman dianggap sebagai pionir dalam menjalankan program membentuk Komite untuk Dialog (Committee for Dialogue). Program ini memprioritaskan dialog dan debat intelektual, dan bertujuan untuk meyakinkan kepada para aktivis kekerasan atau mereka yang tersangkut terorisme bahwa

30 Zakia Daradjat, Dasar-Dasar Agama Islam, Universitas Terbuka, Jakarta, 2002, hlm. 60.

31 Yusuf Qardhawi, Menjadi Muslim Par Excellence, Grafindo, Jakarta, 2004, hlm. 178.

32 Bustanudin Agus, Agama Dalam Kehidupan Manusia, Rajawali Pers, Jakarta, 2006, hlm. 280.

${ }^{33}$ Hal tersebut berdasarkan surat al-Hujjarat ayat (9): "Dan jika ada dua golongan orang-orang mukmin berperang, maka damaikanlah antara keduanya. Jika salah satu dari kedua golongan itu berbuat aniaya terhadap golongan yang lain, maka perangilah golongan yang berbuat aniaya itu, sehingga golongan itu kembali kepada perintah Allah; jika golongan telah kembali (kepada perintah Allah), maka damaikanlah antara keduanya dengan adil dan berlaku adillah. Sesungguhnya Allah menyukai orang-orang yang berbuat adil”. 
pemahaman yang mereka miliki adalah salah. Pelopor program ini adalah Hamoud al-Hittar, yang beranggapan bahwa "Jika anda mempelajari terorisme di dunia, anda akan melihat bahwa ada teori intelektual di belakangnya. Segala bentuk ide intelektual juga bisa dikalahkan oleh intelektual". ${ }^{34}$

Arab Saudi mendesain model yang lebih komprehensif melalui apa yang dikenal dengan istilah PRAC (Prevention, Rehabilitation and After Care) yang dikenal dengan pencegahan, rehabilitasi dan perawatan pasca program. Dilakukan oleh suatu lembaga Lajnah al-Munashahah (Komite Penasihat). Lembaga ini dibentuk pada tahun 2003 dan bernaung di bawah Departemen Dalam Negeri (di bawah pimpinan Deputi II Kabinet dan Menteri Dalam Negeri, Pangeran Nayif bin Abdul Aziz rahimahullah) dan Biro Investigasi Umum. Tugas utama Lajnah alMunashahah adalah memberikan nasihat dan berdialog dengan para narapidana kasus terorisme di penjara- penjara Arab Saudi. Lajnah al-Munashahah terdiri dari 4 (empat) komisi atau sub komite, yaitu: Lajnah 'Ilmiyyah (Komisi Ilmiah); Lajnah Amniyyah (Komisi Keamanan); Lajnah Nafsiyyah Ijtima'iyyah (Komisi Psikologi dan Sosial); Lajnah I'lamiyyah (Komisi media atau Penerangan). ${ }^{35}$

Pada tahap awal, dilakukan pemeriksaan kondisi psikis dan tingkat pengetahuan narapidana untuk kepentingan pengelompokan. Selanjutnya narapidana diwajibkan untuk mengikuti program ceramah antiterorisme yang dilakukan oleh ulama-ulama terkemuka Arab Saudi dan ditayangkan langsung melalui fasilitas televisi yang ada di dalam ruang tahanan, yang di dalamnya juga disediakan sarana komunikasi untuk berdialog langsung dengan penceramah. Bagi mereka yang lulus dalam program tahap pertama kemudian diikutkan dalam program pembinaan terpadu yang dikenal dengan istilah Care Center. Setelah dinyatakan lulus dari semua tahapan program, mereka dibebaskan dan diberikan bekal finansial sebagai modal usaha. ${ }^{36}$

Di Singapura, terdiri dari beberapa komponen, yaitu: rehabilitasi psikologis, rehabilitasi agama, rehabilitasi sosial, dan keterlibatan masyarakat dan dukungan

\footnotetext{
${ }^{34}$ Ismail Hasani dan Bonar Tigor Naipospos (ed), Radikalisme Agama di Jabodetabek. \& Jawa Barat: Implikasinya terhadap Jaminan Kebebasan Beragama atau Berkeyakinan, Pustaka Masyarakat Stara, Jakarta, 2010, hlm. 170.

35 Anas Burhanudi, “Majalah As-Sunnah, Edisi 3 Tahun XV Juli 2011.

36 Ibid.
} 
keluarga. Proses rehabilitasi psikologis dimulai di penjara dengan mengevaluasi narapidana secara teratur. Untuk tujuan ini, pihak berwenang meminta bantuan dari komunitas Muslim Singapura yang memiliki mandat dan otoritas yang diperlukan. Dalam kaitan ini, pada 2003 di Singapura didirikan Religious Rehabilitation Group (RRG). Selain rehabilitasi psikolologi dan dialog teologi, rehabilitasi Sosial dengan melibatkan masyarakat dan keluarga narapidana. Rehabilitasi sosial dilakukan melalui pendidikan dan penyediaan lapangan pekerjaan. ${ }^{37}$

Di Mesir, dialog teologis dengan tujuan meruntuhkan persepsi teroris yang salah dan melakukan konstruksi ulang ideologi yang mendasari tindakan radikal juga dilakukan oleh Pemerintah Mesir. Pemerintah Mesir memfasilitasi pertemuan di antara para tokoh JI Mesir dengan ulama- ulama $A l$-Azhar, inisiatif ini untuk menghentikan aksi kekerasan pun muncul di kalangan para pemimpin JI Mesir. Inisiatif ini dikenal dengan istilah al-mubadarah liwaqfil unfi (proposal atau maklumat penghentian aksi kekerasan). ${ }^{38}$

Pertanyaan selanjutnya apakah secara filosofis penerapan sanksi tindakan merupakan salah satu sarana untuk mewujudkan keadilan bagi pelaku kejahatan terorisme. Keadilan dan kepastian hukum merupakan dua terminologi yang saling berhubungan satu dengan yang lainnya. Secara terminolgis keadilan dipahami sebagai memberi kepada setiap orang apa yang menjadi haknya di satu sisi dan pada sisi yang lain hukum memastikan apa yang menjadi hak setiap orang.

Keadilan lebih menunjukan suatu kondisi yang bersifat hipotetik, imperative, etis yang dapat dipetik dalam kaitannya dengan penegakan hukum yang adil setiap orang harus diasumsikan sama di depan hukum. Kesamaan di depan hukum harus berangkat dari asumsi hipotetik tersebut. Ini berarti bahwa demi keadilan determinasi faktor- faktor yang bersifat komplementer seperti ekonomi, sosial, ras, etnis, jender, politik, dan lain sebagainya harus disangkal. Ketika faktor-faktor

37 Angel Rabasa, Atall, Deradicalizing Islamist Extremists, Santa Monica: RAND Corporation, 2010, hlm. 96.

38 Usman, "Model Deradikalisasi Narapidana Terorisme Studi Perbandingan Deradikalisasi di Yaman, Arab Saudi, Singapura, Mesir dan Indonesia”, Jurnal Inovatif, Volume VII Nomor II Mei, 2014. 
determinan tersebut disangkal maka, akan nampak bahwa semua manusia sama, sederajat, dan setara. ${ }^{39}$

Menurut Hart, prinsip umum keadilan dalam kaitannya dengan hukum menuntut bahwa para individu di hadapan yang lainnya berhak atas kedudukan relatif berupa kesetaraan atau ketidaksetaraan tertentu. Kaidah pokok yang berkaitan dengan prinsip tersebut di atas adalah perlakukan hal-hal serupa dengan cara yang serupa, kendatipun perlu menambahkan padanya dan perlakukanlah hal-hal yang berbeda dengan cara yang berbeda. ${ }^{40}$

Untuk membentuk suatu keadilan bagi setiap orang, maka lahirnya butiran pemikiran yang dijumpai dalam banyak gagasan tentang hukum yang dicetuskan oleh Satjipto Rahardjo. Hukum bukanlah sekedar logika semata, lebih dari pada itu hukum merupakan ilmu sebenarnya (genuine science), melihat hukum sebagai objek ilmu dari pada profesi, dengan selalu berusaha untuk memahami atau melihat kaitan dengan hal-hal di belakang hukum, keinginan untuk melihat logika sosial dari hukum lebih besar dari pada logika hukum atau perundang-undangan, yang seharusnya selalu dimaknai sehingga selalu up to date. Wajah hukum yang normatif (rules), sebagai regularities (pola-pola perilaku) yang terjadi dialam pengalaman dan/atau sebagaimana yang tersimak di dalam kehidupan sehari-hari (sine ira et studio). ${ }^{41}$

\section{Penerapan Sanksi Tindakan dalam Perspektif Teori Hukum}

\section{Pandangan Teori Restorative Justice}

Restorative justice atau sering diterjemahkan sebagai keadilan restoratif ${ }^{4}$ bukanlah konsep yang baru dalam sistem hukum pidana. Restorative justice adalah sebuah konsep pemikiran yang merespon pengembangan sistem peradilan pidana dengan menitikberatkan pada kebutuhan pelibatan masyarakat dan korban yang dirasa tersisihkan dengan mekanisme yang bekerja pada sistem peradilan pidana

\footnotetext{
39 J. Rawls, Teori Keadilan, Dasar-Dasar Filsafat Politik Untuk Mewnjudkan Kesejabteraan Sosial Dalam Negara, Pustaka Pelajar, Yogyakarta, 2006, hlm. 40.

${ }^{40}$ H. L. A. Hart, Konsep Hukum, Nusamedia, Bandung, 2010, hlm. 23.

${ }^{41}$ Soetandyo Wignyosoebroto, "Materi Tutorial Mata Kuliah Penulisan Disertasi untuk Program Doktor Ilmu Hukum Universitas Diponegoro, Semarang, 2001, hlm. 11-15.

42 Eva Achjani Zulfa, Keadilan Restorative Di Indonesia, Ringkasan Disertasi, Universitas Indonesia, 2009, hlm. 1.
} 
yang ada pada saat ini. Keadilan restoratif merupakan suatu pendekatan yang menitikberatkan pada adanya partisipasi langsung pelaku, korban, dan masyarakat dalam proses penyelesaian perkara pidana. Tindakan-tindakan dan program yang merefleksikan tujuan-tujuan restoratif akan dapat menyelesaikan kejehatan dengan cara: a) mengidentifikasi dan mengambil langkah-langkah untuk memulihkan kerugian; b) melibatkan semua stakeholder; dan c) merubah hubungan tradisional antara masyarakat dan pemerintah mereka dalam mengatasi kejahatan terorisme tersebut.

Menurut David Fogel, restorative justice model diajukan kaum Abolisionis yang mengangap bahwa sistem peradilan pidana bermasalah atau cacat struktural sehingga harus diubah dasar-dasar struktur dari sistem tersebut. Analisis paham Abolisionis menurut Brants dan Silvis sebagaimana dikuti Romli Atmasasmita lebih banyak ditujukan terhadap kegagalan dari sistem peradilan pidana dibandingkan terhadap keberhasilannya. ${ }^{43}$

John Braithwhite berpandangan, bahwa restorative justice adalah proses di mana semua pihak yang terlibat pelanggaran tertentu bersama-sama memecahkan secara kolektif bagaimana untuk menghadapi akibat pelanggaran dan implikasinya pada waktu yang akan datang. ${ }^{44}$ Restorative justice harus juga diamati dari sisi kriminologi dan sistem pemasyarakatan karena konsep restorative justice terlahir oleh keadaan sistem pemidanaan yang sekarang berlaku, ternyata belum sepenuhnya menjamin keadilan terpadu (integrated justice), yaitu keadilan bagi pelaku, keadilan bagi korban dan keadilan bagi masyarakat dalam mekanisme di luar peradilan pidana. Model ini diharapkan dapat menyentuh empat aspek dalam perlindungan pelaku terorisme, yaitu pencegahan, penanganan, rehabilitasi dan reintegrasi. 45

\section{Pandangan Teori Gabungan dalam Pemidanaan}

Bidang hukum pidana (termasuk sistem dan proses peradilan pidana) menempati urutan pertama yang tidak hanya mendapat sorotan, tetapi juga

43 Romli Atmasasmita, Sistem Peradilan Pidana : Perspektif Eksistensionalisme dan Abolisionis, Binacipta, Bandung, 1996, hlm. 101.

${ }^{44}$ John Braithwhite, Restorative Justice : Assessing an Immodest Theory and a Pessimistic Theory Draft to be Summated to Crime and Justice: Review of Research, University Of Chicago Press, Chicago, tt, hlm. 5.

45 Ibid. 
mendapat celaan yang luar biasa dibandingkan dengan bidang hukum lainnya. ${ }^{46}$ Diskursus mengenai tujuan pemidanaan telah menjadi pembicaraan dari zamankezaman dan menjadi isu sentral dalam hukum pidana karena pidana atau hukuman selalu berkenaan dengan tindakan-tindakan yang apabila bukan dilakukan oleh negara dengan berlandaskan hukum, maka akan menjadi tindakan yang bertentangan dengan moral. Oleh karena itu, filosofi pemidanaan berusaha mencari pembenaran terhadap tindakan negara ini.

Perkembangan pemikiran tentang hakikat tujuan pemidanaan itu adalah bukan sebagai sarana pembalasan (retributif), melainkan sebagai sarana treatment dan perlindungan sosial (social defence). Tujuan dari pemidanaan itu sendiri seharusnya mengarah kepada perlindungan masyarakat dan pencegahan kejahatan, baik prevensi umum maupun prevensi khusus, yang dalam hal ini mencegah agar pelaku kejahatan terorisme yang semakin tumbuh. Tujuan pemidanaan prevensi umum diharapkan memberikan peringatan kepada masyarakat supaya tidak melakukan kejahatan terorisme. Prevensi khusus dimaksudkan bahwa dengan Tindakan dapat memberikan deterrence effect kepada si pelaku sehingga tidak mengulangi perbuatannya kembali. ${ }^{47}$

Sanksi tindakan dalam pemidanaan dapat mengurangi pelanggaran melalui cara 1) pencegahan terhadap pelaku kejahatan terorisme (deterring the offender), yaitu membujuk si pelaku untuk menahan diri atau tidak melakukan pelanggaran hukum kembali melalui ingatan mereka terhadap pidana yang dijatuhkan; 2) pencegahan terhadap pelaku yang potensial (deterring potential imitators); 3) perbaikan si pelaku (reforming the offender), yaitu memperbaiki tingkah laku si pelaku sehingga muncul kesadaran si pelaku untuk cenderung tidak melakukan kejahatan lagi walaupun tanpa adanya rasa ketakutan dari ancaman pidana; dan 4) mendidik masyarakat supaya lebih serius memikirkan terjadinya kejahatan terorisme, sehingga dengan cara ini, secara tidak langsung dapat mengurangi

${ }^{46}$ Harkristuti Harkrisnowo, "Rekonstruksi Konsep Pemidanaan : Suatu Gugatan Terhadap Proses Legislasi dan Pemidanaan di Indonesia”, Pada Upacara Pengukuhan Guru Besar Tetap dalam Ilmu Hukum Pidana Fakultas Hukum Universitas Indonesia, 2003, hlm. 2.

${ }^{47}$ R. A. Duff and David Garland (Ed.), A Reader on Punishment, Oxford University Press, New York, 1995, hlm. 221. 
frekuensi kejahatan terorisme. ${ }^{48}$ Selain itu juga, sanksi tindakan dalam pemidanaan digunakan sebagai treatment dari tujuan pemidanaan. Argumen aliran positif ini dilandaskan pada alasan bahwa pelaku kejahatan adalah orang yang sakit sehingga membutuhkan tindakan perawatan dan perbaikan. ${ }^{49}$

\section{Pandangan Teori Double Track System}

Rancangan Kitab Undang-Undang Hukum Pidana (KUHP) menganut sistem pemidanaan dua jalur (double track system) di mana di samping pelaku tindak pidana dapat dijatuhi sanksi pidana (criminal puishment), dapat juga dikenakan berbagai tindakan (treatment). Dirumuskannya sanksi pidana dan tindakan tidak lepas dari ide dasar double track system yang menghendaki agar unsur pencelaan/penderitaan dan unsur pembinaan sama-sama diakomodasikan dan adanya kesetaraan dalam sistem sanksi hukum pidana. Paham filsafat yang mengakui kesetaraan antara punishment dan treatment adalah filsafat eksistensialisme dari Albert Camus ayng menyatakan punishment bagi seorang harus diarahkan lewat sanksi yang mendidik (treatment) untuk mencapai bentuknya yang lebih penuh dari manusia. ${ }^{50}$

Ide dasar double track system dalam menjatuhkan sanksi terhadap pelaku terorisme yang melakukan kejahatan sangat tepat untuk diterapkan, karena di samping untuk mengindari dampak negatif pidana hilang kemerdekaan maka pelaku dimungkinkan untuk memperoleh pembinaan guna perkembangan ke depannya. Sanksi pidana dan sanksi Tindakan dapat berjalan secara pararel, seiring dan bersama guna mencapai tujuan dari pemidanaan terhadap pelaku kejahatan.

\section{Formulasi Sanksi Tindakan dalam Revisi Undang-Undang Terorisme}

Menurut Kamus Besar Bahasa Indonesia, formulasi merupakan perumusan. ${ }^{51}$ Formulasi sanksi tindakan dimaksud adalah merumuskan sanksi tindakan dalam revisi undang-undang terorisme mendatang. Teknik formulasi sanksi pidana

\footnotetext{
${ }^{48}$ Negel Walker, Reductivism and Deterrence, Oxford University Press, New York, 1995, hlm. 212.

${ }^{49}$ C. Ray Jeffery, Crime Prevention Through Environmentl Design, SAGE Publication, Inc., Beverly hills London, 1977, hlm. 18.

${ }^{50}$ M. Sholehuddin, Sistem Sanksi Dalam Hukum Pidana : Ide Dasar Double Track System \& Implementasinya, PT Raja Grafindo Persada, Jakarta, 2003, hlm. 130.

${ }^{51}$ Indrawan WS, Kamus Lengkeap Bahasa Indonesia, Lintas Media, Jombang, tt, hlm. 162.
} 
merupakan salah satu politik hukum dalam penyusunan suatu revisi undangundang terorisme. Perumusan sanksi pidana terkait dengan adanya sanksi tindakan dari suatu norma yang sebelumnya ada harus disepakati oleh pembentuk undang-undang. Kesepakatan tersebut dapat diartikan sebagai suatu kebijakan formulasi.

Masalah penentuan pidana tidak terlepas dari pembentukan suatu undangundang, yang mana pada dasarnya merupakan suatu kebijakan politik negara atau kebijakan hukum yang dibentuk oleh Dewan Perwakilan Rakyat dan Presiden. Revisi pemidanaan pelaku terorisme dalam hukum positif diperlukan adanya batasan dan syarat penerapan sanksi tindakan di dalam Revisi Undang-Undang tersebut dalam hal jenis kejahatan dan pelaku kejahatan. Ke depan dalam revisi Undang-Undang No. 15 Tahun 2003 tentang Pemberantasan Tindak Pidana Terorisme jenis kejahatan dan pelaku kejahatan yang dapat dikenakan sanksi tindakan jika jenis dan pelaku tersebut berlandaskan kelemahan ideologi agama yang salah. Pelaku diupayakan dapat merubah orientasi mereka (mens-rea) terhadap keyakinan yang salah dalam actus-rea nya.

Menurut Barda Nawawi Arief, 52 ada perbedaan pola perumusan ancaman pidana penjara antara KUHP dengan UU di luar KUHP. Pada KUHP sistem perumusan digunakan yaitu: 1) Sistem perumusan tunggal, yaitu pidana penjara dirumuskan sebagai satu-satunya jenis sanksi pidana untuk delik yang bersangkutan; dan 2) Sistem perumusan alternatif, yaitu pidana penjara dirumuskan secara alternative dengan jenis sanksi lainnya berdasarkan uruturutan jenis sanksi pidana yang terberat sampai yang paling ringan. Bentuk perumusan ancaman pidana di luar KUHP dipergunakan beberapa sistem perumusan antara lain yaitu: a) Sistem perumusan tunggal atau sistem imperative; b) Sistem perumusan alternative; c) Sistem perumusan kumulatif; dan d) Sistem perumusan kumulatif-alternatif.

Untuk penerapan sanksi Tindakan bagi pelaku kejahatan terorisme, peneliti memiliki gagasan dalam memformulasikan dalam bentuk sistem perumusan kumulatif-alternatif. Keunggulan dari sistem ini adalah Jaksa dapat menuntut dan

52 Barda Nawawi Arief, Op. Cit., hlm. 150-158. 
Hakim dapat memutus dan memilih dengan sebelumnya menilai apakah seorang pelaku dapat diberikan tindakan atau tidak berdasarkan hasil fakta yang ada di persidangan. Sifat sanksi pidana sebagai senjata pamungkas atau ultimum remedium jika dibandingkan dengan sanksi perdata atau sanksi administrasi. Sifat ini sudah menimbulkan kecenderungan untuk menghemat dalam mengadakan sanksi pidana. ${ }^{53}$

Formulasi penerapan sanksi Tindakan yang akan diatur dalam revisi hukum positif tentang terorisme secara kumulatif-alternatif ini dapat diatur secara terpisah dari delik yang diancam pidana. Adapun gagasan atau ide penulis, pengaturan penerapan sanksi Tindakan diberikan pada Pasal tersendiri dalam Undang-undang yang mengatur tentang jenis pidana dan cara melaksanakan pidana tersebut.

Adapun rumusan ketentuannya yaitu:

Pasal X

Jenis Pidana

(1)Pelaku kejahatan terorisme di pidana berdasarkan jenis pidana yang ada dalam undang-undang ini;

(2)Jenis pidana yang dijatuhkan terhadap pelaku kejahatan terorisme adalah pidana pokok dan/atau tindakan;

\section{Pasal XX}

Pidana Pokok

(1)Pidana Pokok terhadap pelaku kejahatan terorisme adalah:

a. Pidana Mati;

b. Pidana Seumur Hidup;

c. Pidana Penjara dalam waktu tertentu;

d. Pidana Denda;

(2)Selain pidana pokok, pelaku kejahatan terorisme dapat diberikan sanksi Tindakan;

\section{Pasal XXX}

Tindakan

(1)Tindakan terhadap Pelaku kejahatan terorisme dapat diberikan terhadap pelaku kejahatan;

(2)Tindakan wajib dilaksanakan bagi yang turut serta melakukan, membantu melakukan dan/atau percobaan melakukan kejahatan terorisme;

(3)Lamanya menjalani Tindakan tidak lebih dari lamanya masa pidana pokok;

(4)Bentuk-bentuk Tindakan dan lembaga yang bertanggungjawab melaksanakan Tindakan terhadap pelaku kejahatan terorisme diatur dalam Peraturan Pemerintah; hlm. 50 .

53 Wirjono Prodjodikoro, Asas-Asas Hukum Pidana di Indonesia, Ctk. Ketiga, Refika Aditama, Bandung, 2003, 


\section{Bentuk Sanksi Tindakan Bagi Pelaku Terorisme}

Selain perubahan jenis dan pola pemidanaan menjadi ultimum remidium, harus diperhatikan juga bentuk-bentuk sanksi tindakan yang dapat ditawarkan sebagai bentuk rekonstruksi pemidanaan sebagai bentuk pembaharuan hukum pidana terkait pemidanaan bagi pelaku Tindak Pidana Terorisme. Peneliti menawarkan ide bentuk-bentuk pemberian sanksi tindakan bagi pelaku terorisme dapat dilakukan dengan cara antara lain:

\section{Program Brainwashing}

Brainwashing atau yang dikenal dengan cuci otak merupakan salah satu tindakan yang dapat mencegah kejahatan terorisme dengan cara doktrinisasi agama secara benar. Masalah terorisme dapat dilihat dari sudut pandang psikologi sosial dan sosiologik. Secara psikologi aksi-aksi terorisme di Indonesia secara umum dipengaruhi oleh dua sebab utama, yaitu : (1) krisis kepercayaan kepada sistem kehidupan sosial politik dan kultur; (2) karena faktor pelemahan ideologi psikologi itu sendiri.

Krisis kepercayaan atas sistem kehidupan sosial politik, hukum, ekonomi maupun pendidikan menyebabkan sebagian orang merasa frustasi, marah, jengkel dan bahkan kecewa dengan keadaan. Kondisi yang demikian ini menghantarkan kehidupan kejiwaan yang labil. Labilitas kehidupan jiwa inilah yang melemahkan pertahanan emosi seseorang sehingga kepadanya sangat mudah dipengaruhi, diprovokasi untuk melakukan pembencian terhadap sistem kehidupan sosial kenegaraan dan pemerintahan yang dianggap bertanggungjawab atas kehidupan sosial pada umumnya. Perilaku kebencian ini dapat mewujud dalam bentuk kelompok yang mengaku atau mengatasnamakan agama, jihad, perjuangan fisabilillah, amar makruf, dan sebagainya. Maka dari itu, adanya brainwashing oleh pemerintah diperlukan dalam hal krisis kepercayaan ini. Brainwashing ini diharapkan dapat memcuci otak para pelaku untuk kembali ke ajaran yang benar bahwa mereka yang mengatasnamakan agama, jihad dan sebagainya adalah salah, dan perlu diperbaiki pemahaman mereka.

\section{Program Deradikalisasi}

Deradikalisasi sendiri berasal dari kata dasar radikal, berasal dari bahasa Latin, radix yang berarti akar (pohon) atau sesuatu yang mendasar. Dalam kamus 
politik, radikal diartikan amat keras menuntut perubahan yang menyangkut undang-undang dan ketentuan pemerintah. ${ }^{54}$ Eko Endarmoko dalam "Tesaurus Bahasa Indonesia," menjelaskan arti radikal sinonim dengan fundamental, mendasar, primer, esensial, ekstrim, fanatik, keras, militan. Jika dikaitkan dengan tindakan seseorang, maka radikal berarti ekstrimis, reaksioner, revolusioner, progresif, liberal, reformis dan seterusnya. ${ }^{55}$ Secara sederhana deradikalisasi dapat dimaknai suatu proses atau upaya untuk menghilangkan radikalisme. 56

Deradikalisasi adalah suatu program penanggulangan aksi-aksi kekerasan, teror dan radikalisme. Program ini melibatkan berbagai pihak dalam pelaksanaannya. Tidak hanya polisi dan aparat keamanan lainnya, tetapi juga seluruh kementerian, lembaga negara, dan civil society : seluruh perguruan tinggi, ulama, dan tokoh masyarakat, hingga institusi dasar dan terkecil dalam sistem sosial yaitu keluarga. Program deradikalisasi ini dibentuk bukan hanya karena rekasi terorisme yang semakin terang-terangan, tetapi juga sebagai upaya untuk mengikis paham garis keras dalam beragama. ${ }^{57}$

Menurut Petrus Reinhard Golose terdapat tiga kunci program deradikalisasi yang amat penting, yakni HUMANIS, SOUL APPROACH, DAN MENYENTUH AKAR RUMPUT. Deradikalisasi ini berupaya membuka wawasan bahwa untuk memberantas terorisme diperlukan penanganan yang lebih serius, terpadu, komprehensif dan berkelanjutan dari multi pihak dengan pendekatan interdisipliner. Sementara RAND Corporation melihat bahwa, deradikalisasi mempunyai makna yang luas, mencakup hal-hal yang bersifat keyakinan, penanganan hukum, hingga pemasyarakatan sebagai upaya mengubah yang radikal menjadi "tidak radikal". 58

Kegiatan Deradikalisasi mencakup 3 (tiga) hal: 1) Rehabilitasi (Pemulihan Akhlak / Perilaku), artinya pemulihan kepada kedudukan atau keadaan yang dahulu atau semula; 2) Reintegrasi (Hidup Bersama \& Rasa Kebersamaan), artinya

\footnotetext{
${ }^{54}$ B.N. Marbun, Kamus Politik, Pustaka Sinar Harapan, Jakarta, 2003, hlm. 462

55 Eko Endarmoko, Tesaurus Bahasa Indonesia, GPU, Jakarta, 2006, hlm. 501.

${ }^{56}$ Petrus Reindhard Golose, Deradikalisasi Terorisme, Humanis, Soul Approach dan Menyentuh Akar Rumput, Yayasan Pengembangan Kajian Ilmu Kepolisian, Jakarta, 2009, hlm. 62.

57 Zuly Qodir, Radikalisme Agama Di Indonesia, Pustaka Pelajar, Yogyakarta, 2014, hlm. 127-128

${ }^{58}$ Ismail Hasani dan Bonar Tigor Naipospos (ed), Radikalisme Agama di Jabodetabek \& Jawa Barat: Implikasinya terhadap Jaminan Kebebasan Beragama/ Berkeyakinan, Pustaka Masyarakat Setara, Jakarta, 2010, hlm. 169.
} 
penyatuan kembali; pengutuhan kembali, yaitu membawa kembali ke dalam persatuan: membawa seseorang atau sesuatu kembali ke dalam kelompok atau kesatuan yang lebih besar setelah sekian lama keluar/terasing; dan 3) Re-edukasi (Belajar Lagi \& Belajar Kembali), artinya pendidikan ulang, dan mengkaji ilmu pengetahuan yang pernah di peroleh, baik pendidikan agama maupun pengetahuan lain sehingga akan membuka cakrawala berpikirnya. ${ }^{59}$

\section{Pemisahan Pemasyarakatan}

Sebagai salah satu sumber daya manusia warga binaan yang merupakan salah satu manusia biasa yang mendapat hukuman berdasarkan putusan hakim, mengisyaratkan bahwa penjatuhan pidana bagi seseorang melalui palu sang hakim pada hakekatnya tidaklah sebagai suatu perbuatan balasa dendam oleh negara, melainkan sebagai imbangan atas tindak pidana yang telah dilakukannya, yang mana dari pada diharapkan akan menghasilkan kesadaran untuk dihari yang akan datang melalui pemberian pengayoman serta pemasyarakatannya di dalam Lembaga Pemasyarakatan dengan sistem Pemasyarakatan.

Adanya pemisahan lembaga pemasyarakatan khusus narapidana terorisme, agar pengayoman warga binaan terorisme lebih mudah untuk dijalankan. Sistem pola pengayoman serta pemsyarakatannya berdasarkan law an order approach dan treatment approach pengayoman warga binaan, dan juga diberikannya pembinaan khusus mengenai pengetahuan agama. Pemisahan lembaga pemasyarakatan untuk para pelaku terrorisme harus di bawah naungan lembaga khusus di luar Kementerian Hukum dan HAM.

\section{Pembentukan Lembaga khusus pelaksanaan sanksi Tindakan}

Dibentuknya badan khusus untuk melaksanakan sanksi Tindakan merupakan alternatif untuk pemerintah dalam pembenahan para narapidana terorisme. Seperti negara-negara lainnya seperti Singapura, Mesir, Arab Saudi yang mempunyai lembaga khusus dalam menagani masalah sanksi tindakan

${ }^{59}$ Endra Wijaya, "Peranan Putusan Pengadilan dalam Program Deradikalisasi Terorisme di Indonesia: Kajian Putusan No. 2189/Pid.B/2007/PN.Jkt.Sel” dalam Jurnal Yudisial Volume III/No.02/Agustus/2000, hlm. 116. 
untuk pelaku kejahatan. Di Indonesia bisa dilakukan oleh lembaga khusus di bawah naungan BNPT yang bekerja sama dengan MUI.

Namun tidak menutup kemungkinan lembaga tersebut berada di bawah naungan Kejaksaan Agung Republik Indonesia sebagai eksekutor putusan pengadilan. Hal ini bertujuan agar pelaksanaan putusan pengadilan dapat lebih efektif pelaksanaannya dan dapat secara riil dipantau oleh pelaksana putusan yaitu Jaksa. Lembaga ini diberikan kewenangan untuk dapat melakukan berbagai macam bentuk tindakan yang telah diatur dalam Peraturan Pemerintah sebagaimana diamanatkan oleh UU.

\section{Penutup}

Berdasarkan uraian di atas dapat disimpulkan bahwa: pertama, Alasan pembenar dalam penerapan sanksi tindakan bagi pelaku kejahatan terosisme didasarkan oleh beberapa dasar, yaitu: pertama, secara filosofis alasan pembenar dalam penerapan sanksi tindakan didasarakan pada; pertama, aliran positif yang beralaskan paham determinisme menyatakan bahwa seseorang melakukan kejahatan bukan berdasarkan kehendak karena manusia tidak mempunyai kehendak bebas dan dibatasi oleh berbagai faktor, sehingga harus diberikan perlakuan (treatment) untuk resosialisasi dan rehabilitasi pelaku kejahatan. Kedua, perlindungan hukum dan keadilan sosial sebagai salah satu nilai yang terkandung dalam Pancasila dan nilai-nilai keadilan harus mengupayakan tercapainya tujuan utama dari pemidanaan. Secara teoritik, penerapan sanksi Tindakan sejalan dengan beberapa teori hukum antara lain Teori pemidanaan gabungan/modern (Vereningings Theorien) Teori ini diperkenalkan oleh Prins, Van Hammel, Van List saat Union Internationale de Droit Penale; Teori Restorative Justice; serta Teori double Track System yang meniscayakan pemberian dua jenis sanksi yaitu sanksi Pidana dan Sanksi tindakan secara pararel dan bersamaan guna mewujudkan tujuan dari pemidanaan itu sendiri. Kedua, perumusan (formulasi) sanksi pidana terkait dengan adanya sanksi tindakan dari suatu norma yang sebelumnya ada harus disepakati oleh pembentuk undang-undang. Kesepakatan tersebut dapat diartikan sebagai suatu kebijakan formulasi. Berkaitan revisi Undang-Undang Terorisme mendatang, perlu adanya batasan dan syarat penerapan sanksi tindakan di dalam 
revisi undang-undang tersebut dalam hal jenis kejahatan dan pelaku kejahatan. Adapun Formulasi penerapan sanksi Tindakan yang akan diatur dalam revisi hukum positif tentang terorisme secara kumulatif-alternatif ini dapat diatur secara terpisah dari delik yang diancam pidana. Ketiga, bentuk-bentuk pemberian sanksi Tindakan bagi pelaku terorisme dapat dilakukan dengan cara: 1) program Brainwashing, 2) program deradikalisasi, 3) Pemisahan pemasyarakatan, dan 4) pembentukan lembaga khusus pelaksanaan sanksi Tindakan, yaitu sebuah lembaga di berada dibawah Kejaksaan Agung selaku Eksekutor putusan pengadilan.

Sebagai kontribusi, peneliti memberikan saran untuk legislatif: agar segera mereformulasikan jenis sanksi terhadap pelaku kejahatan terorisme dengan memasukkan sanksi tindakan dalam revisi UU terorisme mendatang. Untuk Praktisi dan Penegak Hukum: Agar ikut serta mendorong penerapan sanksi Tindakan terhadap pelaku kejahatan terorisme dengan mempertimbangkan penelitian ini bahan diskusi dalam forum Integrated Criminal Justice System (ICJS). Untuk Akademisi: agar penelitian ini menjadi sumber bahan pengetahuan dan bahan kajian dalam forum diskusi akademik baik dalam bentuk workshop, FGD, seminar-seminar atau bahan diskusi perkuliahan sebagai bahan utama perluasan wawasan ilmu hukum pidana khususnya pemidanaan yang berkaitan dengan sanksi Tindakan.

\section{Daftar Pustaka}

\section{Buku}

A. Garner, Bryan, Black's Law Dictionary: English Edition, West Publishing Co, USA, 1990.

Achjani Zulfa, Eva, Pergeseran Paradigma Pemidanaan, Lubuk Agung, Bandung, 2010.

Agus, Bustanudin, Agama Dalam Kehidupan Manusia, Rajawali Pers, Jakarta, 2006.

Ali, Mahrus, Hukum Pidana Teroriseme Teori dan Praktik, Gramata Publishing, Jakarta, 2012.

Ancel, Marc, Sosial Defence, Modern Approach to the Criminal Problem, Roatledge \& Paul Keagen, London 1965. 
Atmasasmita, Romli, Sistem Peradilan Pidana: Perspektif Eksistensionalisme dan Abolisionis, Binacipta, Bandung, 1996.

, Masalah Pengaturan Terorisme dan Perspektif Indonesia, Badan Pembinaan Hukum Nasional Departemen Kehakiman dan HAM RI, Jakarta, 2002.

Basuki, Sulisty, Pengantar Dokumentasi Ilmiah, Kesaint Balanc, Jakarta, 1989.

Braithwhite, John, Restorative Justice : Assessing an Immodest Theory and a Pessimistic Theory Draft to be Summated to Crime and Justice :Review of Research, University of Chicago Press, Chicago, tt.

Daradjat, Zakia, Dasar-Dasar Agama Islam, Universitas Terbuka, Jakarta, 2002.

David Whittaker, J., Terorism Understanding The Global Threat, Pearson Education, London, 2002.

Duff, R. A. and David Garland (Ed.), A Reader on Punishment, Oxford University Press, New York, 1995.

Endarmoko, Eko, Tesaurus Bahasa Indonesia, GPU, Jakarta, 2006.

Hadikusuma, Hilman, Anthropologi Hukum Indonesia, Alumni, Bandung, 1986.

Hamzah, Andi, Kapita Selekta Hukum Pidana Mengenang Oemar Seno Adji, Ghalia Indonesia, Jakarta, 1995.

Harrison Barbet, Antony, Mastering Philosophy, The Macmillan Press Ltd, London, 1990.

Hart, H. L. A, Konsep Hukum, Nusamedia, Bandung, 2010.

Hasani, Ismail dan Bonar Tigor Naipospos (ed), Radikalisme Agama di Jabodetabek $\mathcal{E}$ Jawa Barat: Implikasinya terhadap Jaminan Kebebasan Beragama/ Berkeyakinan, Pustaka Masyarakat Setara, Jakarta, 2010.

L. Packer, Herbert, The limits Of The Criminal Sanction, Stanford University Press, 1986.

Marbun, B.N., Kamus Politik, Pustaka Sinar Harapan, Jakarta, 2003.

Masyar, Ali, Gaya Indonesia Menghadang Terorisme : Sebuah Kritik Atas Kebijakan Hukum Pidana Terhadap Tindak Pidana Terorisme di Indonesia, CV. Mandar Maju, Bandung, 2009.

MS Bakry, Noor, Pancasila Yuridis Kenegaraan, Liberty, Yogyakarta, 1994.

Muladi dan Barda Nawawi Arief, Teori-Teori dan Kebijakan Hukum Pidana, Alumni, Bandung, 2010.

Nawawi Arief, Barda, Kebiiakan Legislatif Dalam Penanggulangan Kejahatan dengan Pidana Penjara, Universitas Diponegoro, Semarang, 1994.

Prodjodikoro, Wirjono, Asas-Asas Hukum Pidana di Indonesia, Ctk. Ketiga, Refika Aditama, Bandung, 2003.

Qardhawi, Yusuf, Menjadi Muslim Par Excellence, Grafindo, Jakarta, 2004. 
Qodir, Zuly, Radikalisme Agama Di Indonesia, Pustaka Pelajar, Yogyakarta, 2014.

Rabasa, Angel, at all, Deradicalizing Islamist Extremists, RAND Corporation, Santa Monica, 2010.

Ray Jeffery, C., Crime Prevention Through Environmentl Design, Beverly hills London, SAGE Publication, Inc., 1977.

Rawls, J., Teori Keadilan, Dasar-Dasar Filsafat Politik Untuk Mewujudkan Kesejahteraan Sosial Dalam Negara, Pustaka Pelajar, Yogyakarta, 2006.

Reindhard Golose, Petrus, Deradikalisasi Terorisme, Humanis, Soul Approach dan Menyentuh Akar Rumput, Yayasan Pengembangan Kajian Ilmu Kepolisian, Jakarta, 2009.

Robert Lily, J., et, al., Criminological Theory, Context and Consequences, SAGE Publication, London, 1995.

Sahetapy, J.E., Pidana Mati Dalam Negara Pancasila, Citra Aditya, Bandung, 2007.

Saleh, Roeslan, Stelsel Pidana Indonesia, Aksara Baru, Jakarta, 1983.

Sedarmayanti \& Syarifudin Hidayat, Metodologi Penelitian, CV. Mandar Maju, Bandung, 2002.

Sholehuddin, M., Sistem Sanksi Dalam Hukum Pidana: Ide Dasar Double Track System $\mathcal{E}$ Implementasinya, PT Raja Grafindo Persada, Jakarta, 2003.

Soekanto, Soerjono, Pengantar Penelitian Hukum, Grafindo, Jakarta, 2006. Pengantar Penelitian Hukum, Ctk. Ketiga, UI Press, Jakarta, 2010.

WS., Indrawan, Kamus Lengkap Bahasa Indonesia, Lintas Media, Jombang, tt.

Wahid, Abdul, Dkk., Kejahatan Terorisme : Perspektif Agama, HAM dan Hukum,: PT Refika Aditama, Bandung, 2004.

Walker, Negel, Reductivism and deterrence, Oxford University Press, New York, 1995.

Zainudin Ali, H., Metode Penelitian Hukum, Sinar Grafika, Jakarta, 2009.

\section{Artikel Jurnal}

Kholiq, M.A. dan Ari Wibowo,"Penerapan Teori Tujuan Pemidanaan dalam Perkara Kekerasan terhadap Perempuan: Studi Putusan Hakim" dalam Jurnal Hukum Ius Quia Iustum, No. 2 Volume 23 April 2016.

Pradityo, Randy, “Kebijakan Hukum Pidana dalam Upaya Penganggulangan Tindak Pidana Pendanaan Terorisme" dalam Jurnal Rechtsvinding, Volume 5, Nomor 1, April 2016.

Usman, "Model Deradikalisasi Narapidana Terorisme Studi Perbandingan Deradikalisasi Di Yaman, Arab Saudi, Singapura, Mesir dan Indonesia", Jurnal Inovatif, Volume VII Nomor II Mei (2014). 
Wijaya, Endra, "Peranan Putusan Pengadilan dalam Program Deradikalisasi Terorisme di Indonesia: Kajian Putusan No. 2189/Pid.B/2007/PN.Jkt.Sel" dalam Jurnal Yudisial Volume III/No.02/Agustus/2000.

\section{Makalah/Pidato}

Harkrisnowo, Harkristuti, "Rekonstruksi Konsep Pemidanaan: Suatu Gugatan Terhadap Proses Legislasi dan Pemidanaan di Indonesia", Pada Upacara Pengukuhan Guru Besar Tetap dalam Ilmu Hukum Pidana Fakultas Hukum Universitas Indonesia, 2003.

Utomo, Setyo, "Sistem Pemidanaan dalam Hukum Pidana yang Berbasis Restorative Justice", Makalah disampaikan dalam kegiatan Focus Group Discussion (FGD) tentang "Politik Perumusan Ancaman Pidana dalam Undang-Undang di luar KUHP", diselenggarakan oleh Pusat Perencanaan Pembangunan Hukum Nasional Badan Pembinaan Hukum Nasional (BPHN) Departement Hukum dan HAM, di Jakarta, tanggal 21 Oktober 2010.

\section{Majalah}

Burhanudi, Anas, “Majalah As-Sunnah, Edisi 3 Tahun XV Juli 2011.

\section{Peraturan Perundang-Undangan}

Undang-Undang Dasar Tahun 1945 (UUD 1945).

Kitab Undang-Undang Hukum Pidana (KUHP).

Peraturan Pemerintah Pengganti Undang-Undang Nomor 1 Tahun 2002 tentang Pemberantasan Tindak Pidana Terorisme

Undang-Undang Nomor 15 Tahun 2003 tentang Penetapan Peraturan Pemerintah Pengganti Undang-Undang Nomor 1 Tahun 2002 tentang Pemberantasan Tindak Pidana Terorisme, Menjadi Undang-Undang.

Rancangan Undang-Undang Hukum Pidana (RUU KUHP).

\section{Internet}

http:/ / huda-drchairulhudashmh.blogspot.co.id/2016/01/uregensi-revisiundang-undang-teroris me.html, diakses tanggal 15 Maret 2016.

https: / /www.tempo.co/read/kolom/2016/11/22/2429/penjara-takmembuatnya-jera, diakses pada tanggal 15 Juli 2016. 